\title{
VALUES AND ATTITUDES IN BANAT MULTIETHNIC COMMUNITIES
}

\author{
ILEANA SIMONA DABU \\ Department of Sociology, Faculty of Sociology and Psychology, West University of Timișoara, Romania
}

(C) 2019 Simona Dabu

This is an open access article distributed under the Creative Commons Attribution-NonCommercial-NoDerivs license (http://creativecommons.org/licenses/by-nc-nd/3.0/)

DOI: 10.1515/eras-2019-0001

\begin{abstract}
The Banat area is considered an area of interculturality and multilingualism, an area where there is an interference of cultures, a continuous dialogue between cultures and spiritualties. Banat, being a multicultural and multiethnic space, is a model of harmonious coexistence between the many ethnic groups that make it up. In the present research we have aimed at identifying the individual values of the inhabitants of the studied communities and the attitudes towards the others (Romanians, Serbs, Hungarians, Germans, Bulgarians and other ethnic groups), and also their attitudes towards work, land, church, trust in state institutions and traditional occupations.
\end{abstract}

\section{Keywords}

multicultural and multiethnic space, rural community, multiethnic communities, values, attitudes

\section{The evolution of Romanian communities}

The rural community is a social group that has a specific organization based on the stable relationships of families, the land in that area, with a social communication style of transmitting the history and characteristic cultural values. "Today's Romanian village, in most cases, is no longer a balanced organic reality, but a reality that has entered a powerful process of disintegration" (Bernea, 2006, 5).

The liberal revolution in our country has succeeded in founding a bourgeois civilization, following a pattern with strong Western influences. A new state was founded and several settlements were developed, aiming to the progress of the entire civilization. At the same time, everyday life saw simple population growing up alongside the land, with its people and its events. The village was lead and managed, but this failed to meet the needs of village life. To understand the Romanian village one must see through its values, not through materialistic mentality (Bernea, 2006, 5).

There are many contradictory views about the Romanian village. It has been presented as the area where poverty prevails or as a favorable economic zone. Here, there are also two situations: the first in which the rural population has to move to the city in order to progress, or that when the city moves to the village to do the same. The changes in the Romanian village were those of the property regime, the worsening of the general situation, the need to leave the estates to find better living conditions, the bounding to land, etc. (Pitulac, 2009, 46). Constantin Rădulescu-Motru said that if the villages were left to their own will, they would develop in the spirit of tradition, thus being model settlements: "thus the peasant's soul, instead of showing itself as it is: religious, traditionalist, consecrated, we find it baptized with 
imported labels: liberal or democrat (Rădulescu-Motru, 1992, 344).

The rural area consists of all the activities that take place outside the city, with three main components: administrative communities, dispensation of population, collective services and the important economic role that agriculture and forestry have. The rural environment is characterized by: reduced population density; the human settlement pattern is the villages and communes that are defined by the individuality and discontinuity of the built space; the productive activity is predominantly agricultural and forestry, but may also be agricultural production and rural trade; relations between people are based on mutual knowledge (Moga, Radulescu, 2004, 132).

The fact that people return to rural and non-agricultural activities in rural areas can be considered as a return to biological balance. This can also be due to the return to a place where the noxious elements of the city are not present.

The development of industry, services and commerce has led to the agglomeration of the urban environment and this has also affected to a certain extent the rural environment, thus the evolution of the industry is characterized by the concentration of the economic activity and the population. The necessity of labor force, the bigger and safer income, the comfort found in the urban area, all led to the migration of a significant number of people to the urban environment, and this resulted in a massive decrease of the rural population (Moga, Rădulescu, 2004, 134).

\section{Description of the studied communities}

The Banat area is considered an area of interculturality and multilingualism, an area in which there is an interference of cultures, a continuous dialogue between cultures and spiritualties. Banat, being a multicultural and multiethnic space, is a model of harmonious coexistence between the many ethnic groups that make it up.

For this study, multiethnic communities from the Banat area were selected, more precisely from Timis County, namely: Cenei, Dudeştii Vechi and Tomnatic. These communities were chosen according to the large number of German, Hungarian, Serb and Bulgarian ethnics living in the Banat area, Timiş County (according to the 2011 Population Census).

In Cenei, the population was mainly Serbian, but after 1990 there was a significant decrease among the Serbian and German population, and an increase of Romanians and Hungarians. However, in the Cenei commune, out of a total of 2670 inhabitants, according to the 2011 Population Census, there are: 1795 Romanians, 235 Hungarians, 13 Roma, 3 Ukrainians, 39 Germans, 430 Serbs, 3 Slovaks, 3 Croatians, 145 other undeclared ethnicities. Among the notable events in this commune, together with the village belonging to it, we can mention the following: the patronage of the Serbian Orthodox Church in Cenei on July 26, the patron of the Romanian Orthodox Church in Cenei on August 15, Kirchwei in Cenei on the last Sunday of August (although the German ethnics are a minority, yet the event is held), the patronage of the Romanian Orthodox Church in Bobda on Pentecost, Harvest Day finalized with the Grapes Ball in October and the Harvest Day. Here, in Cenei, there is an ethnical group that hasn't been censored. Moreover, the group is also missing from the ethnic composition of the commune displayed on the town hall's website. I am talking about the Roma community in this locality. They represent a concealed minority, one that does not recognize its own identity, on the other hand builds its identity in the village by referring to the Romanian and Serbian communities here. This community of "Serbs" is established in a "neighborhood" of the village, named by the inhabitants of Cenei as the "Gypsy area". This area is located at the edge of the village. The settlement of the Roma at the village limits was not accidental, being directly related to one of the group's traditional occupations, because at 
the exit of the village there was a virgin land area where animal fairs were held. Near this "neighborhood" is the Jewish cemetery, abandoned today, but the only indication that once there was a Jewish community in that part of the village.

Interviewees recall the Serbian and German areas, both grouped around the churches of the two communities, and fail to recall the Roma or any others.

On the other hand, all interviewees claim that the Roma are a community that has long lived in this locality. However, the Roma appear in no census (in 2011 they are declared 13). It seems that they did not declare their own identity, but they related to the identity of the group they feel attached to by language, religion and culture.

Indeed, the Roma population in Cenei is Serbian-speaking and attends the Serbian Orthodox Church in the locality. The children are baptized at this church and are enrolled in the Serbian kindergarten and in the local Serbian school. Their identity, manifested in relation to the other inhabitants, is Serbian. In the presence of others, they speak Serbian, especially the elders.

Different by occupation, mentality and by their location in the perimeter of the locality, identified indirectly by the others in the village through the area (the Gypsy area) in which they live, the Roma have built up their group identity on a prestigious local cultural identity.

With this option, the Roma actually contribute - given that the number of Serbs, who were the founders of the locality, the majority group, has become smaller than the number of Romanians - to the consolidation of the Serbian cultural identity in its relation to the Romanian culture.

The Old Dudesti is a commune with a not very large number of inhabitants, namely 4203, the Bulgarian ethnic population being much higher than the Romanian population. There are 1122 Romanians, 159 Hungarians, 222 Roma, 8 Ukrainians, 27 Germans, 6 Serbs, 6 Slovaks, 2439 Bulgarians, and other 212 undeclared ethnicities in Dudeştii Vechi, with the villages of Cheglevici and the Bulgarian Colony. Of all the communities studied in this research, there is an amalgam of ethnicities in Dudeştii Vechi that live together peacefully, sometimes blending their particular customs. If between the different ethnic groups here and Romanians there were intermarriages, the Bulgarian ethnicity in the rural area did not marry members of any other ethnical groups, so the Bulgarians married only Bulgarians. The Bulgarians from Dudestii Vechi kept their identity unchanged, which is language and culture. They have kept their own words, beliefs, specific folk costumes, which over time they have improved with floral motifs. However, nowadays Bulgarians agree to marry Romanians, even other nationalities. Dudeştii Vechi has cooperation relationships with various localities in the neighboring countries, Serbia and Hungary, as well as a twinning with Biela Slatina in Bulgaria. In the locality there is a Museum of the Bulgarian Union of Banat and the Bulgarian House, which hosts events of the Union of Bulgarians in Banat.

Here too, during Communism, because there were also Orthodox Romanians in the commune, there was an intent to build an Orthodox church, that was not completed and later became Cultural Home.

The Orthodox Church in Dudeştii Vechi is in a house donated by a local personality. The house was thus transformed into an Orthodox church. An attraction for any man who comes for the first time in this community is the Bulgarian Church - a historical monument, which was built in 1803 and is of indescribable beauty, still surviving.

Dudestii Vechi benefits, on the basis of the proposed objectives, from various projects with external financing or co-financing, that were undertaken at the time of the research. These are: the rehabilitation of the local cultural center, the extension and modernization of the centralized water supply system in the commune, the establishment of a sewerage network 
and a sewage treatment plant in the commune, the afforestation of degraded agricultural land (environmental fund).

One very interesting aspect is that in the Bulgarian Colony now lives only a family of Bulgarians, the rest of the six families being from other parts of the country and raising animals.

The rest of the inhabitants of this locality sold their homes and went to Dudestii Vechi or Cheglevici. The village is deserted, leaving only a few buildings and a Catholic church, also left in ruins. The Bulgarian Colony was founded at the time of Maria Theresa, when the people of Dudestii Vechi received land and house plots, moving there and establishing the community.

Like the Orthodox Church in Dudeştii-Vechi, the one in Cheglevici was also transformed from a house that was donated by a native 50-60 years ago. Now this place of worship is under renovation, Sunday services are carried out once every two weeks, because the priest also goes to the Orthodox Parish of Cenad.

In Cheglevici there is also a Roman Catholic Church, where the Sunday service is held in Romanian, not in German, Hungarian or Bulgarian, as it once was, remember the locals. Here too, Sunday service is held every two weeks.

Among the most important cultural and religious manifestations of this community are the following: the Catholic "Ruga" in Dudeștii Vechi (August 15th), Cheglevici (September 21st) and the Bulgarian Colony (September 18th) - although this is established, a church service; the Orthodox "Ruga" in Dudeştii Vechi (June 29th) and Cheglevici (October 26th). All members of the community, regardless of ethnicity or social status, participate in these events.

In Tomnatic, beside the 2466 Romanians, there are also 125 Hungarians, 213 Roma, 45 Ukrainians, 122 Germans, 9 Serbs, 15 Bulgarians, the total number of inhabitants in the commune being 3144, according to the 2011 population census. A mentionable fact is that the number of ethnic Germans in this locality is highly compared to the Germans in the other studied localities.

Tomnatic has no satellite villages, the commune being formed only by Tomnatic. Here one can see the Monument of Heroes, a Roman Catholic Church, documented since 1796, a Romanian Orthodox Church, built in 1980 and a Pentecostal Church from 2006.

The commune has various objectives. Among these, the most important are the following: building a cultural home; rehabilitation of roads; realization of a sewage system. One of the external projects with external financing or co-financing, which is underway, consists in the afforestation of 22 hectares. In Tomnatic commune there is a weekly agro-food fair, a fair where people from the villages around the commune come to sell their products.

The most important cultural and religious manifestation in this commune is the local "Ruga" (Prayer), which takes place on September 8th and where the various ethnical groups of the locality participate.

\section{Values and attitudes in the studied communities. Goal values of residents in multi-ethnic communities}

In the present research we have aimed at identifying the individual values of the inhabitants of the studied communities and the attitudes towards the others (Romanians, Serbs, Hungarians, Germans, Bulgarians and even other ethnic groups) and also their attitudes towards work, land, church an trust in state institutions and traditional occupations.

The term value means a set of material and spiritual goods, that is the qualities of persons, goods, activities, any being or thing, object of nature, society and thought of as valuable because either they are the result of labor (material values) or they satisfy a particular 
need (useful values) or an expectation, an aspiration, an ideal (ideal values).

I have tried to identify the purposeful values of the inhabitants of the studied communities and their importance to them. Based on the interviews and the chart described in the table below, we evaluated the importance of the identified values with grades from 1 to 10 .

\begin{tabular}{|c|c|c|c|c|c|c|c|c|c|c|c|}
\hline 1. & Professional achievement & 1 & 2 & 3 & 4 & 5 & 6 & 7 & 8 & 9 & 10 \\
\hline 2. & Information/continuous training & 1 & 2 & 3 & 4 & 5 & 6 & 7 & 8 & 9 & 10 \\
\hline 3. & $\begin{array}{l}\text { Personal development } \\
\text { cultural) }\end{array}$ (spiritual, & 1 & 2 & 3 & 4 & 5 & 6 & 7 & 8 & 9 & 10 \\
\hline 4. & Familial fulfilment & 1 & 2 & 3 & 4 & 5 & 6 & 7 & 8 & 9 & 10 \\
\hline 5. & Social status (respect, prestige) & 1 & 2 & 3 & 4 & 5 & 6 & 7 & 8 & 9 & 10 \\
\hline 6. & $\begin{array}{l}\text { Material achievements (house, money, } \\
\text { car, land, tools, livestock) }\end{array}$ & 1 & 2 & 3 & 4 & 5 & 6 & 7 & 8 & 9 & 10 \\
\hline 7. & $\begin{array}{l}\text { Social relations } \\
\begin{array}{l}\text { (with } \\
\text { relatives, friends, local } \\
\text { solidarity) }\end{array}\end{array}$ & 1 & 2 & 3 & 4 & 5 & 6 & 7 & 8 & 9 & 10 \\
\hline 8. & $\begin{array}{l}\text { Social recognition (recognized work, } \\
\text { being considered by others as an active } \\
\text { member of the community, being } \\
\text { respected ) }\end{array}$ & 1 & 2 & 3 & 4 & 5 & 6 & 7 & 8 & 9 & 10 \\
\hline 9. & Travels, adventure, novelty, diversity & 1 & 2 & 3 & 4 & 5 & 6 & 7 & 8 & 9 & 10 \\
\hline 10. & Parties, fun, holidays, lack of worries & 1 & 2 & 3 & 4 & 5 & 6 & 7 & 8 & 9 & 10 \\
\hline
\end{tabular}

\section{Values-individual purposes Source: Concept of the author}

The largest share, in descending order, was seen in the following items: for Serbs, Bulgarians and Hungarians - family fulfillment (life partner, children, living with family); material achievement (house, money, machine, earth, agricultural tools, animals); parties, joy, feast, lack of care; social relations (a good relation with neighbors, relatives, friends, local authorities, solidarity); and to the Romanians and Germans in the studied communities - the material realization (house, money, machine, earth, agricultural tools, animals), family fulfillment (life partner, children); parties, joy, feast, lack of care; social relations (understanding with neighbors, relatives, friends, local authorities, solidarity). The least important is for Serbs, Bulgarians and Hungarians - continuous information / training, and for Romanians and Bulgarians - journeys, adventure, novelty, diversity.

In the hierarchy of purposeful values, there are similarities in the answers of ethnic Serbs, Hungarians, Bulgarians and those of Romanians and Germans, which shows that regardless of ethnicity and the community in which they live, there are similarities in the rural area of Timis county, generating specific value options. Differences result from different living conditions in the studied communities.

\section{Values on which family and households are based}

Family and implicitly the household were once based on the decision of the parents of future married young people, when the dowry of each of them was established. Usually the girl left as a daughter-in-law in the boy's home. Very rarely the opposite happens. Thus, in a 
household one could find two or three generations living together.

It should be said that a defining characteristic of Romanians and most of the Banat ethnic groups (except the Bulgarian one, who practiced endogamy, establishing their families only within their ethnic group, one of the arguments being the fear from the disintegration of the family's wealth) was the coexistence of several generations in a household. This aspect has had beneficial effects not only in the material state of the family, which has been prosperous through the existence of numerous working hands, as well as for the education of children and the transmission of production habits in the household. In the case of mixed marriages, it is interesting that when the newborn family brought a child into the world, the language the child spoke when it grew was the language of the mother. We can say that this habit of family ties is also practiced as a strategy to strengthen the bond between ethnicities through marriage.

Most women in the Romanian villages of Banat, regardless of ethnicity, do not work, they are domestic, and the responsibility they feel is to affectively support the family through their permanent presence.

Family and its values is an important feature, both for Romanians and for other ethnic groups with whom they live together. Mothers, in general, care for their own children, but also for others. This care is doubled by an admiration, and their son / daughter is considered "the most beautiful, clever / smart, hardworking / diligent". Their qualities are amplified and attributed to heredity "he/she resembles ...", and defects are accidents whose cause is unknown or attributed to unknown ancestors. Even in popular folk tales and poems such expressions are encountered as: "He/she is a piece of stars" etc. Marriage is considered an act that implies obligations and responsibilities related to good living; therefore, the prospect of a life with shortages, without the safety of tomorrow, often suppresses love: "Poverty enters the door and love goes out the window" is a proverb often encountered in the studied communities. The attitude of the spouses towards each other is determined by each role and contribution to the well-being of the family. "Where there is no man in the house, there is no maize on the table" or "The man is the pillar of the house". In order to emphasize the role of the woman in the family, they compare the man with the head of the family, and the woman with its neck: "Where the neck turns his head ...". Also, in order to highlight the qualities of a woman in any marriage, she is attributed merits that make the man succeed in whatever he does.

\section{Conclusions}

The village and its world of values, irrespective of ethnic composition, though under the influence of external and internal changes, has influenced the behavior of the peasant who remained at home, but also of the person who left for the city. This sensitive behavior for any ethnical group meant: modesty, temperance, common sense, respect, fear of not being wrong, not being a nuisance; all these are a lesson of life learned from the experience of parents and grandparents who have labored their whole life for a modest living, compared to those in the city who at least had a sure monthly income. Nonetheless, things have changed. The safety of the place of work remains history, the comforts of the city block buildings could also be achieved in the village, the city mirage has proved to be deceiving in the absence of values such as goodness, justice, and equality.

\section{REFERENCES}

Berne, Ernest, (2006), Romanian Rural Civilization, Bucharest, Vremea Publishing House.

Moga, Toader, Rădulescu, Carmen-Valentina, (2004), The Complex Development of Rural Space, Bucharest, 
Ileana Simona Dabu, Values and attitudes in Banat multiethnic communities

DOI: 10.1515/eras-2019-0001

ASE Publishing House

Rădulescu-Motru, Constantin, (1992), Romanianism, Bucharest, Scientific Publishing House. 